\title{
Knowledge Discovery Data Akademik Untuk Prediksi Pengunduran Diri Calon Mahasiswa
}

\author{
I Gst Ayu Sri Melati ${ }^{1}$ Linawati $^{2}$, I A Dwi Giriantari ${ }^{3}$
}

\begin{abstract}
New Students Registration at an educational institution such as STMIK STIKOM Bali is a routinely implemented every new academic year. Whereas the registration of new student candidates is always increasing from year to year, but not all prospective students continued registration to further step after they passed the selection. It would be too late to take corrective action if very few new students enrolled. By not knowing how to estimate the number of registratration students, the institution cannot measure the time and the number of new admissions target to be achieve. In this case the use of data mining technique is proposed to provide knowledge that was previously hidden in the data warehouse. Representation of 2017 prospective student data has the lowest accuracy of $78 \%$ and student representation 2017,2016 has $78.46 \%$ accuracy and student representation $2017,2016,2015$ has $78.20 \%$ accuracy. The result of the frequent itemsets mining process shows that the emergence of advanced and backward labels is also frequent with the appearance of the emergence trend between criteria and label (advanced or backward). Task mining then is used to predict the prospective student is by classification techniques and frequent pattern. The software used for implementation is WEKA
\end{abstract}

Keywords: Data Mining, Classification, Decision Tree, Frequent Pattern, Knowledge Discovery.

Intisari- Pendaftaran Mahasiswa Baru pada suatu institusi pendidikan seperti STMIK STIKOM Bali adalah sebuah kegiatan yang rutin dilaksanakan setiap tahun ajaran baru. Pendaftaran calon mahasiswa baru tersebut selalu meningkat dari tahun ketahun namun calon mahasiswa yang melakukan pendaftaran tidak semua yang melanjutkan kelangkah registrasi dari sejumlah calon mahasiswa yang sudah dinyatakan lulus. Hal ini akan menjadi sangat terlambat untuk mengambil tindakan apabila ternyata mahasiswa baru yang registrasi sangat sedikit jumlahnya. Dengan tidak diketahuinya mahasiswa yang registrasi, maka pihak-pihak perguruan tinggi tidak dapat mengetahui dengan pasti kapan jumlah target penerimaan mahasiswa baru tercapai. Dalam permasalahan ini penggunaan teknik data mining diharapkan dapat memberikan pengetahuan - pengetahuan yang sebelumnya tersembunyi di dalam gudang data. Representasi data calon mahasiswa 2017 memiliki akurasi paling rendah yaitu $78 \%$ dan representasi calon mahasiswa 2017 , 2016 memiliki akurasi 78,46\% dan representasi calon mahasiswa 2017, 2016, 2015 memiliki akurasi 78,20\%. Hasil proses frequent itemsets mining menunjukkan bahwa kemunculan label lanjut dan mundur juga frequent dengan kemunculan trend kemunculan antara kriteria dengan label (lanjut atau mundur). Task mining yang digunakan untuk memprediksi calon mahasiswa yaitu dengan teknik klasifikasi dan teknik Frequent

\footnotetext{
Mahasiswa, Magister Teknik Elektro, Program Pasca Sarjana Universitas Udayana, email : geamell87@yahoo.com

${ }^{3}$ Staff Pengajar, Magister Teknik Elektro, Program Pasca Sarjana Universitas Udayana, Jl. PB. Sudirman Denpasara Bali, Telp. (0361239599); email : linawati@unud.ac.id,dayu.giriantari@unud.ac.id
}

I Gst Ayu Sri Melati dkk: Knowledge Discovery Data ...
Pattern. Perangkat lunak yang digunakan untuk implementasi adalah WEKA.

Kata Kunci-Data Mining, Klasifikasi, Decision Tree, Frequent Pattern, Knowledge Discovery.

\section{PENDAHULUAN}

Perkembangan teknologi informasi telah memberikan kontribusi pada cepatnya pertumbuhan jumlah data yang dikumpulkan dan disimpan dalam basis data berukuran besar (gunung data). Data mining adalah proses mencari pola atau informasi menarik dalam data terpilih dengan menggunakan teknik atau metode [1].

STMIK STIKOM BALI adalah salah satu sekolah tinggi manajemen informatika yang berdiri di Pulau Bali. Penerimaan mahasiswa baru pada suatu institusi pendidikan seperti STIKOM Bali adalah sebuah kegiatan yang selalu dilaksanakan setiap tahun ajaran baru. Pendaftaran calon mahasiswa baru tersebut selalu meningkat dari tahun ketahun sebesar 20-50\% berdasarkan data akademik namun calon mahasiswa yang melakukan pendaftaran tidak semua yang melanjutkan kelangkah registrasi. Oleh karena itu dibuat sebuah prediksi dari kemungkinan pengunduran diri calon mahasiswa.

Dalam permasalahan ini klasifikasi prediksi dapat digunakan pada Penerimaan Mahasiswa Baru (PMB). Data berskala besar memunculkan fenomena data yang berjumlah besar tidak diikuti dengan peningkatan informasi yang didapat dari data tersebut [2]. Pada kasus ini model klasifikasi di buat untuk mengidentifikasi pola data untuk kelas status "lanjut" atau "mundur pendaftaran", dari hasil penentuan pola training data [3]. Pola atau model dari training data tersebut selanjutnya diuji dengan menggunakan test set data.

Model klasifikasi dibuat dengan menganalisis training data. pengklasifikasian data yang bekerja relatif dengan cara yang lebih sederhana dibandingkan dengan metode pengklasifikasian data lainnya. Algoritma ini berusaha mengklasifikasikan data baru yang belum diketahui class-nya dengan memilih data sejumlah $k$ yang letaknya terdekat dari data baru tersebut [4]

Model yang dihasilkan kemudian dapat digunakan untuk memprediksi kelas dari unknown data, test set data digunakan untuk pengujian dari model yang telah didapatkan pada training data

Dengan menerapkan beberapa metode yang telah dijabarkan di atas, diharapkan penulis dapat menganalisis pemanfaatan data calon mahasiswa untuk membangun model klasifikasi (classifier) dan pemanfaatan frequent itemsets mining pada data pendaftaran mahasiswa baru untuk memprediksi kemungkinan pengunduran diri calon mahasiswa. Perangkat lunak yang digunakan untuk implementasi adalah WEKA.

p-ISSN:1693 - 2951; e-ISSN: 2503-2372 


\section{METODE PENELITIAN}

\section{A. Data Mining}

Data mining adalah tahap analisis proses "knowledge discovery in database". Data mining adalah proses darimenganalisis data dari perspektif yang berbeda dan meringkasnya menjadi informasi yang [5]. Data Mining merupakan salah satu teknik penting dalam mencari pengetahuan dalam sekumpulan data digital (knowledge mining from data) [6]. Hasil pencarian ini dapat dimanfaatkan untuk memprediksi "masa depan" dan menemukan tren berdasarkan pola dan relasi data.

Dalam penerapan data mining diperlukan berbagai perangkat lunak untuk menganalisis data guna mencari data hubungan dan pola yang dapat digunakan untuk membuat prediksi secara akurat [7].

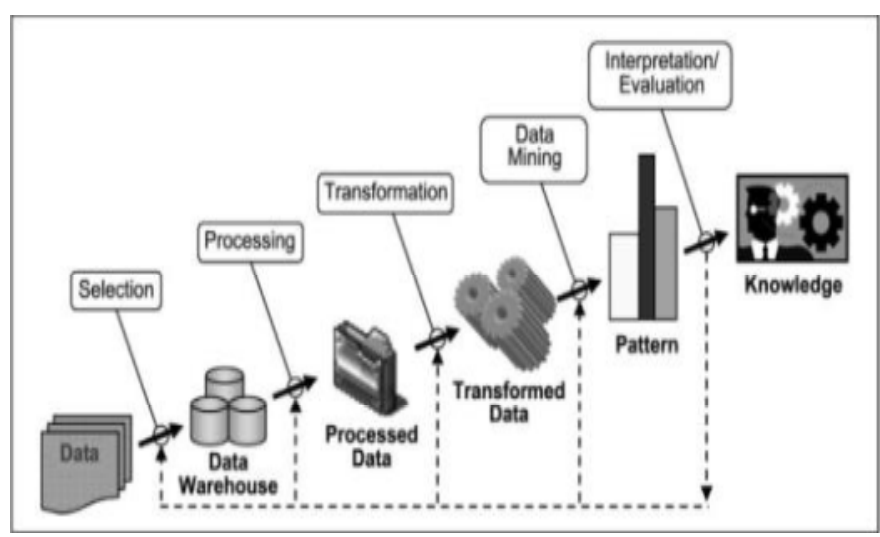

Gambar 1. Tahapan Data Mining [6]

a. Data Selections

Memilih atau mensegmentasikan data sesuai dengan beberapa kriteria.

b. Pre-Processing dan Cleaning Data

Tahap pembersihan data dilakukan dengan menghapus informasi tertentu yang dianggap tidak perlu dan bias karena memperlambat kueri

c. Transformation

Data tidak hanya ditransfer tetapi ditransformasikan dalam lapisan dapat ditambahkan seperti lapisan demografis yang umum digunakan dalam riset pasar

d. Data Mining

Tahap ini berkaitan dengan ekstraksi pola dari data sebuah pola dapat didefinisikan sebagai seperangkat fakta (data).

e. Interpretation / Evakuasi

Pola yang didefinisikan oleh sistem ditafsirkan menjadi pengetahuan yang kemudian dapat digunakan untuk mendukung pengambilan keputusan.

\section{B. Frequent Pattern}

Frequent Patterns (FP) merupakan kumpulan pola (seperti itemsets, subsequences, atau substructures) yang sering muncul di dalam data set [4]. Itemset merupakan kumpulan items yang muncul bersamaan dalam sebuah dataset. Subsequence merupakan sekumpulan itemset yang berurutan (berdasarkan waktu atau posisi pada satu ID), jika suatu itemset sering berurutan dengan itemset yang lain maka dikatakan frequent sequential pattern.

\section{Klasifikasi Data}

Klasifikasi data (data Classification) adalah sebuah bentuk analisis data yang mengektrak model dan mengambarkan kelas data penting. Model disebut pengklasifikasi, memprediksi kategoris (diskrit, unordered) label kelas [6]

Sebuah model klasifikasi atau Classifier dibentuk untuk memprediksi class (categorical) label. Jadi, dalam data yang akan dibangun model klasifikasi hasus sudah ditentukan variable yang akan dijadikan class label. Class / label / kategori dapat diwakili oleh nilai - nilai diskrit, urutan antara nilai - nilai tidak ada artinya atau diabaikan [6].

\section{Decision Tree}

Decision tree adalah sebuah diagram alir yang berbentuk seperti struktur pohon yang mana setiap internal node menyatakan pengujian terhadap suatu atribut, setiap cabang menyatakan hasil dari pengujian dan leaf node (simpul terminal) menyatakan kelas - kelas atau distribusi kelas [6] Decision Tree adalah struktur rekursif sederhana untuk mengekspresikan sebuah proses klasifikasi sekuensial di mana sebuah kasus, yang digambarkan oleh serangkaian atribut, ditugaskan ke salah satu kelas yang terpisah [8]

\section{E. Ekstraksi Decision Tree Menjadi Aturan Klasifikasi}

Ekstraksi decision tree menjadi aturan (rule) klasifikasi dilakukan setelah proses pruning dilakukan atau setelah decision tree terbentuk secara optimal. Ekstraksi decision tree menjadi aturan klasifikasi akan menghasilkan aturan yang berbentuk IF - THEN. Aturan IF-Then adalah ekspresi dari bentuk [4]. IF condition THEN conclution Contoh aturan R1: R1: IF age = youth AND student = yes THEN buys computer $=$ yes. Jika decision tree pada gambar (decision tree membeli computer) dirubah menjadi aturan IF-THEN.

\section{F. Algoritma J48}

Decision Tree J48 merupakan implementasi algoritma C4.5 (berbasis Java) pada Weka. Algoritma C4.5 digunakan untuk pemisah obyek. Tree atau pohon keputusan banyak dikenal sebagai bagian dari Graph, yang termasuk dalam irisan bidang ilmu otomata dan teori bahasa serta matematika diskrit [9]. Untuk memilih atribut sebagai akar, didasarkan pada nilai gain tertinggi dari atribut-atribut yang ada. Untuk menghitung gain digunakan persamaan sebagai berikut:

$\operatorname{Gains}(S, A)=\operatorname{Entropy}(s)-\sum^{n} * \operatorname{Entropy}(s I)$

Keterangan:

$\mathrm{S}=$ himpunan kasus

$\mathrm{A}=$ atribut

$\mathrm{n}=$ jumlah partisi atribut $\mathrm{A}$

$|\mathrm{Si}|=$ jumlah kasus pada partisi ke-i

Confusion matrix adalah tool yang dipergunakan untuk mengukur seberapa akurat model klasifikasi (classifier) dalam memprediksi class label dari tuples [4]. TP dan TN menunjukkan classifier melakukan prediksi secara tepat, sedangkan FP dan FN menunjukkan classifier melakukan salah prediksi. 


\section{Predicted classs}

Actual class

\begin{tabular}{|c|c|c|l|l|}
\hline & & yes & no & Total \\
\cline { 1 - 3 } Yes & & TP & $F N$ & $P$ \\
No & & $F P$ & $T N$ & $N$ \\
\hline Total & & $P^{2}$ & $N^{2}$ & $P+N$ \\
\hline
\end{tabular}

Dari confusion matrix pada TABEL I model klasifikasi dapat dihitung nilai akurasinya, recall, precision dan F-meansure. Berikut adalah tabel formula pengukuran model klasifikasi [6] TABEL II Formula Pengukuran klasifikasi Data.

TABEL II

FORMULA PENGUKURAN KLASIFIKASI DATA

\begin{tabular}{|l|c|}
\hline Meansure & Formula \\
\hline Accuracy, recognition rate & $\frac{\mathrm{TP}+\mathrm{TN}}{P+N}$ \\
\hline $\begin{array}{l}\text { Sensitivity, true positive rate, } \\
\text { Recall }\end{array}$ & $\frac{\mathrm{TP}}{P}$ \\
\hline $\begin{array}{l}\text { Precision } \\
\begin{array}{l}\text { F, F1, F-scare, harmonic mean of } \\
\text { precision and recall }\end{array}\end{array}$ & $\frac{\mathrm{TP}}{\mathrm{TP}+\mathrm{FP}}$ \\
\hline
\end{tabular}

\section{G. WEKA Data Mining Tools}

WEKA adalah sebuah paket tools macine learning praktis. WEKA merupakan singkatan dari Waikato Environment for Knowlegde Analysis, yang dibuat di Universitas Waikato. New Zealand untuk penelitian, pendidikan dan berbagai aplikasi.

Beberapa format file untuk inputnya diantaranya:

1. Format Comma Separated values (CSV) Merupakan format file teks dengan pemisah tanda koma (,) yang cukup umum digunakan. Bias membuat file ini dengan menggunakan Microsoft Exsel atau membuat sendiri dengan format notepad

2. Attribute Relation File Format (ARFF) Merupakan tipe file teks yang berisi beberapa instance data yang berhubungan dengan suatu set atribut data yang dideskripsikan juga dalam file tersebut.

\section{PERANCANGAN SISTEM}

A. Klasifikasi

Berdasarkan permasalahan yang ada yaitu memprediksi kemungkinan pengunduran diri calon mahasiswa baru, hasil prediksinya berupa lanjut atau mengundurkan diri sebagai calon mahasiswa. Dari beberapa teknik data mining klasifikasi dan teknik Frequent Pattern sangat memungkinkan sekali dalam memprediksi sebuah label. Beberapa tahapan perancangan alur analisis digambarkan pada Gambar 2.

I Gst Ayu Sri Melati dkk: Knowledge Discovery Data ...

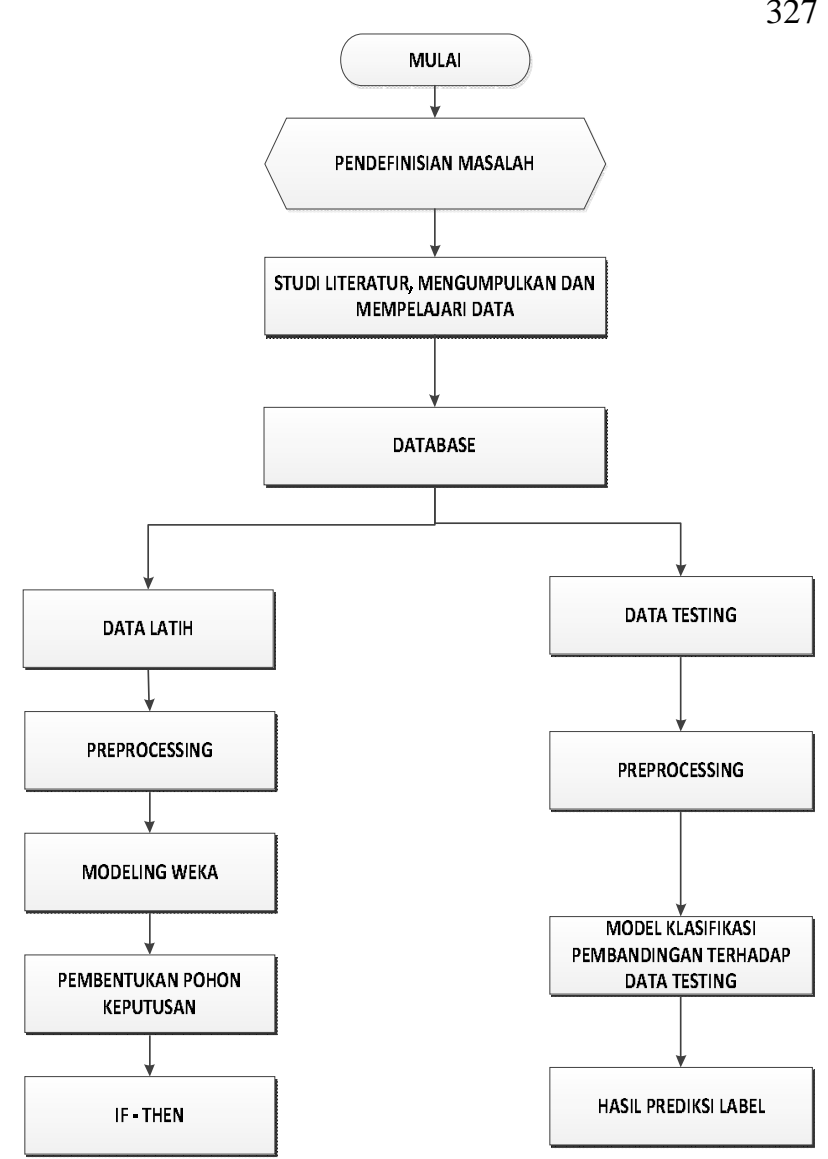

Gambar 2 Alur Analisis Klasifikasi Prediksi Pengunduran Diri Calon Mahasiswa

1. Pendefinisian Masalah

Pendefinisian masalah melingkupi penjabaran masalah yang akan ditangani data akademik mengandung informasi dan pengetahuan yang bermanfaat untuk mendukung prediksi kemungkinan pengunduran diri calon mahasiswa

2. Teknik Klasifikasi

Data latih yang di ambil dari data akademik PMB 3 tahun terakhir yaitu tahun 2015, 2016, 2017. Dari data latih akan dibuatkan 3 buah model klasifikasi yaitu: Model I : Data akademik PMB Thn 2017.

Model II : Data akademik PMB Thn 2017, 2016

Model III : Data akademik PMB Thn 2017, 2016, 2015.

Dalam analisi Pembentukan Pohon Keputusan Pembentukan decision tree yaitu pembentukan diagram alir yang berbentuk seperti struktur pohon yang mana setiap internal node menyatakan pengujian terhadap satu atribut. Diperoleh IF - THEN: decision tree menjadi aturan klasifikasi akan menghasilkan aturan yang berbentuk IF THEN.

Aturan IF-Then adalah ekspresi dari bentuk IF condition THEN conclution.

B. Analisis Pembentukan Itemsets Dari Data Calon Mahasiswa

p-ISSN:1693 - 2951; e-ISSN: 2503-2372 
Hasil Analisis menunjukkan dalam teknik frequent pattern yang dapat digunakan sebagai bahan pertimbangan adalah yang pertama gelombang sebagai rentan waktu pendaftaran, jenis sekolah dan jurusan menetukan kompetensi dari calon mahasiswa kemudian pekerjaan orang tua sebagai penentu finansisal. Untuk membangkitkan frequent pattern (FP) pada data calon mahasiswa maka data gelombang, jenis sekolah, jurusan, pekerjaan orang tua sebagai sekumpulan item.

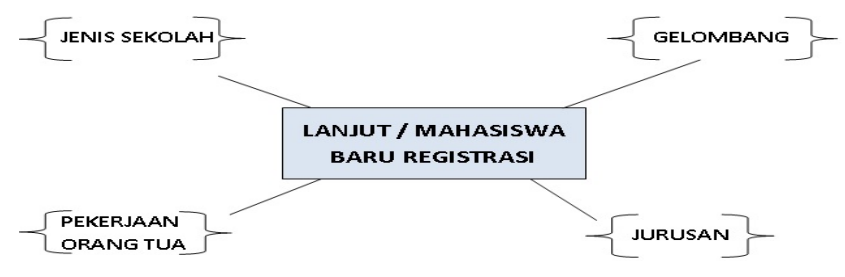

Gambar 3 Analisis Pembentukan Itemsets Calon mahasiswa Registrasi

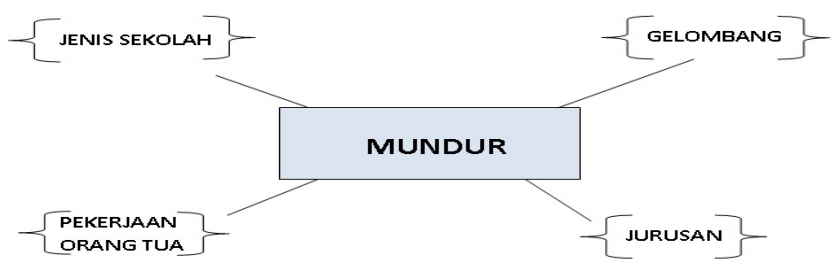

Gambar 4 Analisis Pembentukan Itemsets Calon Mahasiswa Mundur

\section{HASIL DAN PEMBAHASAN}

\section{A. Data Pembentukan dan Pengujian Klasifikasi}

Data pembentukan dan pengujian klasifikasi menggunakan data calon mahasiswa dalam tahun 2017, 2016, 2015. Data pembentukan classifier menggunakan data calon mahasiswa pada kampus STMIK STIKOM Bali, sedangkan untuk data uji menggunakan data model yang di gunakan 60\% sebagai data uji dari jumlah data tahun 2017, 2016, 2015. Pada tabel berikut akan ditampilkan komposisi dari masing-masing data calon mahasiswa yang digunakan.

TABEL III

PERSENTASE DATA TRAINING DAN DATA TESTING

\begin{tabular}{|c|l|c|c|}
\hline \multirow{2}{*}{ Area Data } & Tahun & Jumlah Data & $\begin{array}{c}\text { Presentase } \\
\text { Data } \\
\text { Training } \\
\text { Model (60\%) }\end{array}$ \\
\hline STMIK & 2017 & 2706 & 1691 \\
\cline { 2 - 4 } Stikom & 2017,2016 & 5332 & 3393 \\
\cline { 2 - 4 } Bali & $2017,2016,2015$ & 5746 & 2591 \\
\hline
\end{tabular}

Data pembentukan classifier menggunakan data calon mahasiswa pada kampus STMIK STIKOM Bali setelah dilakukan proses prepocesing yaitu langkah membersihkan data dengan missing values, noise data pembentukan kriteria dan pembentukan label setelah itu data calon mahasiswa akan di rubah dalam bentuk data $A R F F$ yang diuji pada perangkat lunak yang digunakan untuk implementasi adalah WEKA dengan menggunakan metode C.45 jika di WEKA dinamanakan dengan algoritma J.48.

B. Hasil Pengujian Klasifikasi Representasi Tahun 2017

Hasil pengujian klasifikasi menggunakan representasi data calon mahasiswa Tahun 2017 dilihat dari sisi akurasi keseluruhan yaitu tabel calon mahasiswa 2017 dan nilai perhitungan dengan confusion matrix. Hasil perhitungan confution matrix menghasilkan nilai precision, recall dan $F$ meansure detail dari setiap class. Dataset yang disediakan untuk memprediksi pengunduran diri calon mahasiswa jumlah data calon mahasiswa 2706 dari data calon mahasiswa tahun 2017 adalah 60\% dari jumlah data digunakan sebagai data model adalah 1691 data calon mahasiswa.

TABEL IV

CORRECTLY DAN INCORRECTLY REPRESENTASI CALON MAHASISWA 2017

\begin{tabular}{|c|c|c|c|}
\hline Area Data & Data 2017 & Correctly & Incorrectly \\
\hline $\begin{array}{c}\text { STIKOM } \\
\text { BALI }\end{array}$ & 1691 & $78.06 \%$ & $21.94 \%$ \\
\hline
\end{tabular}

TABEL V

AKURASI DETAIL KLASIFIKASI DATA CALON MAHASISWA

\begin{tabular}{|c|l|l|l|l|l|}
\hline TF & FP & PRECISION & RECALL & $\begin{array}{c}\text { F- } \\
\text { MEASURE }\end{array}$ & CLASS \\
\hline 1 & 1 & 0,781 & 1 & 0.877 & LANJUT \\
\hline 0 & 0 & 0 & 0 & 0 & MUNDUR \\
\hline
\end{tabular}

C. Hasil Pengujian Klasifikasi Menggunakan Klasifikasi Representasi Model 2017, 2016

Hasil confusion matrix menghasilkan nilai precision, recall dan F-meansure detail dari setiap class, dan dipisahkan sesuai data model klasifikasi. Dataset yang disediakan untuk memprediksi pengunduran diri calon mahasiswa jumlah data calon mahasiswa 5332 dari data calon mahasiswa tahun 2017, 2016 adalah $60 \%$ dari jumlah data digunakan sebagai data model adalah 3357 data calon mahasiswa.

Hasil perhitungan confusion matrix pada data 2017, 2016 ditunjukkan pada TABEL VI

TABELVI

CORRECTLY DAN INCORRECTLY REPRESENTASI CALON MAHASISWA 2017, 2016

\begin{tabular}{|c|c|c|c|}
\hline Area Data & $\begin{array}{c}\text { Data } \\
2017.2016\end{array}$ & Correctly & Incorrectly \\
\hline $\begin{array}{c}\text { STIKOM } \\
\text { BALI }\end{array}$ & 3357 & $78,46 \%$ & $21,54 \%$ \\
\hline
\end{tabular}

Akurasi Detail menggunakan confusion matrix pada pengujian menggunakan data 2017, 2016.

TABEL VII

AKURASI DETAIL KLASIFIKASI DATA CALON MAHASISWA

\begin{tabular}{|c|c|c|c|c|c|}
\hline$T F$ & $F P$ & PRECISION & RECALL & $\begin{array}{c}F- \\
\text { MEASURE }\end{array}$ & CLASS \\
\hline 1 & 1 & 0,785 & 1 & 0,879 & LANJUT \\
\hline 0 & 0 & 0 & 0 & 0,499 & MUNDUR \\
\hline
\end{tabular}

D. Hasil Pengujian Klasifikasi Menggunakan Klasifikasi representasi Model 2017, 2016, 2015

Hasil perhitungan confusion matrix menghasilkan nilai precision, recall dan $F$-meansure detail dari setiap class, dan dipisahkan sesuai data model klasifikasi. Dataset yang disediakan untuk memprediksi pengunduran diri calon mahasiswa jumlah data calon mahasiswa 5746 dari data calon mahasiswa tahun 2017, 2016, 2015 adalah 60\% dari jumlah data digunakan sebagai data model adalah 4968 data calon 
Majalah Ilmiah Teknologi Elektro, Vol. 17, No. 3, September - Desember 2018

DOI: https://doi.org/10.24843/MITE.2018.v17i03.P04

mahasiswa. Hasil perhitungan confusion matrix pada data 2017, 2016, 2015 ditunjukkan pada TABEL VIII

TABEL VIII

CORRECTLY DAN INCORRECTLY REPRESENTASI CALON MAHASISWA 2017, 2016, 2015

\begin{tabular}{|c|c|c|c|}
\hline Area Data & $\begin{array}{c}\text { Data } \\
2017.2016,2015\end{array}$ & Correctly & Incorrectly \\
\hline STIKOM & 4968 & $78.20 \%$ & $21.80 \%$ \\
\hline
\end{tabular}

TABEL IX

AKURASI DETAIL KLASIFIKASI DATA CALON MAHASISWA

\begin{tabular}{|l|l|l|l|l|l|}
\hline TF & FP & Precision & Recall & F-measure & Class \\
\hline 0,99 & 0,964 & 0,787 & 0,99 & 0,877 & Lanjut \\
\hline 0,036 & 0,01 & 0,491 & 0,036 & 0,067 & Mundur \\
& & & & & \\
\hline
\end{tabular}

E. Evaluasi Hasil Pengujian klasifikasi data Calon Mahasiswa

Hasil pengujian pertama menggunakan data testing dari data calon mahasiswa. Hasil pengujian tersebut disajikan dalam Confusion matrix, yang kemudian digunakan untuk menghitung rata-rata dari precision, recall, F-meansure dan accuracy. Berikut adalah TABEL $\mathrm{X}$ perbandingan dari hasil pengujian klasifikasi menggunakan representasi data calon mahasiswa tahun 2017, 2016, 2015.

TABEL $\mathrm{X}$

PERBANDINGAN AKURASI CALON MAHASISWA

\begin{tabular}{|c|c|c|c|c|c|c|}
\hline \multirow[b]{2}{*}{ Representasi } & \multicolumn{5}{|c|}{ Weighted Average } & \multirow[b]{2}{*}{ Akurasi } \\
\hline & $\mathrm{TF}$ & FP & $\begin{array}{l}\text { Precisi } \\
\text { on }\end{array}$ & Recall & $\begin{array}{c}\text { F- } \\
\text { Meus } \\
\text { ure }\end{array}$ & \\
\hline $\begin{array}{c}\text { Calon } \\
\text { Mahasiswa } \\
2017\end{array}$ & 0,781 & 0,781 & 0,609 & 0,781 & 0,684 & $78 \%$ \\
\hline $\begin{array}{c}\text { Calon } \\
\text { Mahasiswa } \\
2017,2016\end{array}$ & 0,785 & 0,785 & 0,616 & 0,785 & 0,69 & $\begin{array}{c}78,46 \\
\%\end{array}$ \\
\hline $\begin{array}{c}\text { Calon } \\
\text { Mahasiswa } \\
2017,2016, \\
2015\end{array}$ & 0,782 & 0,756 & 0,722 & 0,782 & 0,7 & $\begin{array}{c}78,20 \\
\%\end{array}$ \\
\hline
\end{tabular}

Hasil pengujian menggunakan data cama dalam kurun waktu 3 tahun menunjukkan bahwa ada peningkatan dari model 2017 ke model 2017,2016 begitu juga ada peningkatan kembali dari data 2017,2016,2015. Semakin banyak data yang digunakan untuk membuat model klasifikasi maka akurasi dan F-meansure akan semakin meningkat walaupun tidak signifikan.

\section{F. Pembentukan Frequent Pattern}

Proses pembentukan frequent pattern menggunakan data calon mahasiswa tahun 2017, 2016, 2015. Berikut adalah pembentukan data calon mahasiswa dari data tiga tahun menggunakan item $\{\{$ gelombang $\}$, \{jurusan $\}$, \{jenis sekolah $\}$, \{pekerjaan_Orangtua\}, \{label\}\} dari item yang dibentuk set itemsets pada data calon mahasiswa tiga tahun dalam pembentukan set itemsetsnya \{calon_mahasiswa1\}, \{calon_mahsiswa2\}.

\{calon_mahsiswa3\},\{calon_mahasiswa\},

I Gst Ayu Sri Melati dkk: Knowledge Discovery Data ...
\{calon_mahsiswaN\}\}. Kemudian itemset yang dibentuk adalah \{IA, IPA, SMAN Mundur\}. Support/minimum support yang digunakan $10 \%$ dari data calon mahasiswa.

TABEL XI

MINIMUM SUPORT LANJUT ITEMSETS 2

\begin{tabular}{|c|c|c|}
\hline Nama_Itemsets1 & Itemsets_2 & Jumlah Kemunculan \\
\hline TIDAK_BEKERJA & LANJUT & 2668 \\
\hline SMK_S & LANJUT & 1128 \\
\hline IPA & LANJUT & 892 \\
\hline SMA_N & LANJUT & 873 \\
\hline KOMPUTER & LANJUT & 791 \\
\hline SMA_S & LANJUT & 462 \\
\hline I_A & LANJUT & 440 \\
\hline LAIN-LAIN & LANJUT & 434 \\
\hline IPS & LANJUT & 388 \\
\hline SMK_N & LANJUT & 315 \\
\hline I_B & LANJUT & 271 \\
\hline II_C & LANJUT & 252 \\
\hline II_B & LANJUT & 244 \\
\hline IV_C & LANJUT & 213 \\
\hline III_B & LANJUT & 203 \\
\hline III_A & LANJUT & 175 \\
\hline IV_B & LANJUT & 174 \\
\hline I_C & LANJUT & 173 \\
\hline SISIPAN_II & LANJUT & 147 \\
\hline IV_A & LANJUT & 141 \\
\hline LAIN-LAIN & LANJUT & 140 \\
\hline SISIPAN_I & LANJUT & 113 \\
\hline II_A & LANJUT & 97 \\
\hline ADMINISTRASI & LANJUT & 66 \\
\hline BAHASA & LANJUT & 61 \\
\hline PARIWISATA & LANJUT & 45 \\
\hline MESIN_OTOMOTIF & LANJUT & 39 \\
\hline ELEKTRO & LANJUT & 31 \\
\hline SEDERAJAT & LANJUT & 31 \\
\hline KESEHATAN & LANJUT & 15 \\
\hline MANAJAMEN & LANJUT & 14 \\
\hline AGAMA & LANJUT & 11 \\
\hline LISTRIK & LANJUT & 7 \\
\hline ARSITEKTUR & LANJUT & 6 \\
\hline BOGA & LANJUT & 4 \\
\hline
\end{tabular}

p-ISSN:1693 - 2951; e-ISSN: 2503-2372 


\begin{tabular}{|l|l|c|}
\hline Nama_Itemsets1 & Itemsets_2 & Jumlah Kemunculan \\
\hline BUSANA & LANJUT & 2 \\
\hline SENI & LANJUT & 2 \\
\hline EKONOMI & LANJUT & 1 \\
\hline PENGACARA & LANJUT & 1 \\
\hline
\end{tabular}

\begin{tabular}{|l|l|c|}
\hline \multicolumn{1}{|c|}{ Nama_Itemsets1 } & Itemsets_2 & $\begin{array}{c}\text { Jumlah } \\
\text { Kemunculan }\end{array}$ \\
\hline MANAJAMEN & MUNDUR & 1 \\
\hline PENGACARA & MUNDUR & 1 \\
\hline
\end{tabular}

TABEL XII

MINIMUM SUPORT MUNDUR ITEMSETS_2

\begin{tabular}{|c|c|c|}
\hline Nama_Itemsets1 & Itemsets_2 & $\begin{array}{c}\text { Jumlah } \\
\text { Kemunculan }\end{array}$ \\
\hline TIDAK_BEKERJA & MUNDUR & 734 \\
\hline SMA_N & MUNDUR & 345 \\
\hline IPA & MUNDUR & 336 \\
\hline SMK_S & MUNDUR & 212 \\
\hline LAIN-LAIN & MUNDUR & 139 \\
\hline SMA_S & MUNDUR & 139 \\
\hline KOMPUTER & MUNDUR & 135 \\
\hline I_A & MUNDUR & 128 \\
\hline IPS & MUNDUR & 109 \\
\hline I_B & MUNDUR & 91 \\
\hline SMK_N & MUNDUR & 75 \\
\hline I_C & MUNDUR & 74 \\
\hline II_C & MUNDUR & 67 \\
\hline II_B & MUNDUR & 54 \\
\hline III_B & MUNDUR & 54 \\
\hline IV_C & MUNDUR & 53 \\
\hline III_C & MUNDUR & 50 \\
\hline III_A & MUNDUR & 47 \\
\hline LAIN-LAIN & MUNDUR & 47 \\
\hline IV_B & MUNDUR & 44 \\
\hline IV_A & MUNDUR & 33 \\
\hline SISIPAN_I & MUNDUR & 30 \\
\hline SISIPAN_II & MUNDUR & 30 \\
\hline II_A & MUNDUR & 27 \\
\hline ADMINISTRASI & MUNDUR & 14 \\
\hline BAHASA & MUNDUR & 12 \\
\hline SEDERAJAT & MUNDUR & 11 \\
\hline PARIWISATA & MUNDUR & 10 \\
\hline ELEKTRO & MUNDUR & 7 \\
\hline MESIN_OTOMOTIF & MUNDUR & 7 \\
\hline ARSITEKTUR & MUNDUR & 4 \\
\hline KESEHATAN & MUNDUR & 3 \\
\hline AGAMA & MUNDUR & 2 \\
\hline LISTRIK & MUNDUR & 2 \\
\hline BOGA & MUNDUR & 1 \\
\hline
\end{tabular}

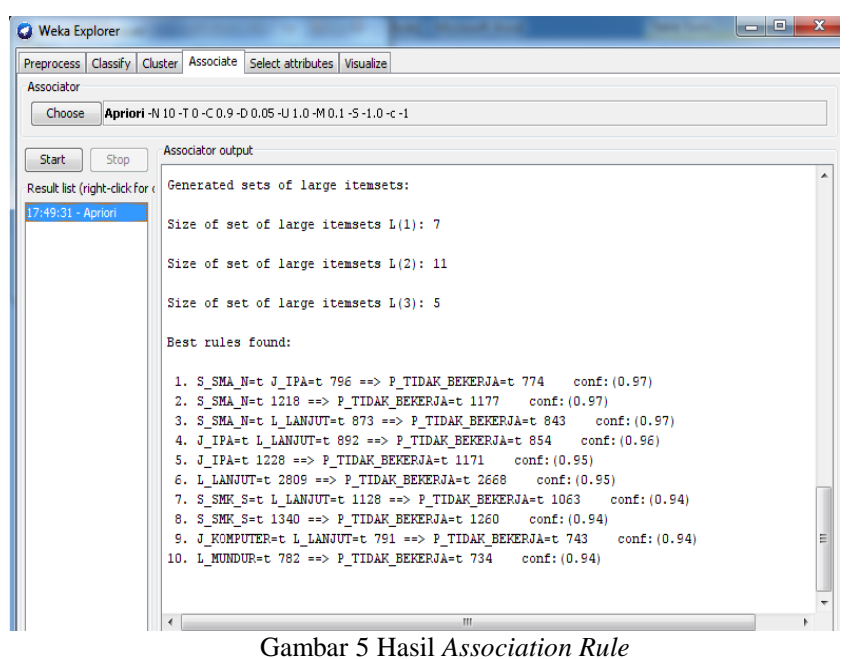

Frequent itemsets mining menunjukkan kemunculan L_LANJUT $\cap$ P_Tidak_Bekerja memiliki nilai support paling tinggi yaitu 2668. Frequent itemset yang kuat juga ditunjukkan oleh rule 8, yaitu S_SMK_S $\cap$ P_Tidak_Bekerja dengan nilai support 1260 dan rule 2 yang berisi S_SMA_N $\cap$ P_Tidak_Bekerja dengan nilai support 1177. Dari hasil frequent itemsets tersebut potensi L_LANJUT $\cap$ P_Tidak_Bekerja sering muncul bersama jenis P_Tidak_Bekerja. Sedangkan, association rule mining menunjukkan bahwa alterasi L_MUNDUR dan L_MUNDUR menjadi confident, ini artinya jika items mendukung telah terpenuhi maka kemungkinan $\mathbf{L} \_$MUNDUR dan L_MUNDUR.

\section{KESIMPULAN}

Hasil pengujian menunjukkan, analisis knowledge discovery data akademik untuk prediksi pengunduran diri calon mahasiswa menggunakan teknik klasifikasi dan teknik frequent pattern dapat membantu program pendaftaran mahasiswa baru dalam mengurangi risiko kekurangan dalam mendapatkan mahasiswa. Klasifikasi (classifier) menggunakan data calon mahasiswa dapat mendukung keputusan pada kampus STMIK STIKOM Bali menjadi lebih kuantitatif dalam menentukan para pendaftar di STMIK STIKOM Bali. Hasil proses frequent itemsets mining menunjukkan bahwa kemunculan label lanjut dan mundur juga frequent dengan kemunculan pekerjaan ortu. Dari hasil frequent itemsets mining dan association rule dapat disimpulkan frequent itemset dapat menampilkan trend kemunculan antara kriteria dengan label (lanjut atau mundur). Sedangkan association justru tidak menampilkan asosiasi rool mining antar label dengan kriteria.

Dari Teknik klasifikasi dengan hasil pengujian pada data calon mahasiswa pada kampus STMIK STIKOM Bali Representasi data calon mahasiswa 2017 memiliki akurasi paling rendah yaitu $78 \%$ dan representasi calon mahasiswa 2017, 2016 memiliki akurasi 78,46\% dan representasi calon 
mahasiswa 2017, 2016, 2015 memiliki akurasi 78,20\%. Pada saat pengujian menggunakan data model klasifikasi nilai akurasi meningkat serta precision, recall dan $F$-meansure juga meningkat. Semakin banyak data yang digunakan untuk membuat model klasifikasi maka akurasi dan F-meansure akan semakin meningkat walaupun tidak signifikan. Teknik frequent itemsets mining menunjukkan kemunculan memiliki nilai support paling tinggi yaitu 2668. Frequent itemset yang kuat juga ditunjukkan oleh S_SMK_S $\cap$ P_Tidak Bekerja dengan nilai support 1260 dan S_SMA_N $\cap$ P_Tidak_Bekerja dengan nilai support 1177.Calon mahasiswa yang berasal dari SMA_N dan (atau) jurusan IPA berpotensi mundur. Sedangkan item tidak bekerja memiliki nilai frequent dengan label mundur juga tinggi yaitu 734 hal ini dapat menjadi pengetahuan bahwa orang tua calon mahasiswa yang memiliki pekerjaan tidak tetap juga berpotensi mundur.

\section{REFERENSI}

[1] Han Jiwai, Kamber, Pei, 2012, "Data Mining Concepts and Tecniques Third Edition". Morgan Kaufman Publishers

[2] Adie Wahyudi Oktavia G, I Ketut Gede Darma Putra, I Putu Agung Bayupati, "Implementasi Algoritma Apriori Untuk Menemukan Frequent Itemset Dalam Keranjang Belanja” Majalah Ilmiah Teknologi Elektro Universitas Udayana, Vol. 15, No.2, Juli -Desember 2016

[3] Anddri, Yesi Novaria Kunang, Sri Murniati, 2013 "Implementasi Teknik Data Mining Untuk Memprediksi Tingkat Kelulusan Mahasiswa Pada Universal Bina Darma Palembang”. Nasional Informatika 2013.

[4] I Gede Harsemadi, Made Sudarma, Nyoman Pramaita' "Implementasi Algoritma K-Nearest Neighbor Pda Perangkat Lunak Pengelompokan Musil Untuk Menentukan Suasana Hati”, Majalah Ilmiah Teknologi Elektro Universitas Udayana Vol. 16, No.1, Januari -April 2017

[5] Ankita A Nichat, Dr. Anjali B Raut. 2017. "Predicting and Analysis of Student Performance Using Decision Tree Techniqie". International Journal Vol 52017

[6] Han Jiawai, Pei Jian, Yin Yuwen, Mao Runying. "Mining Frequent Pattern Candidate Generation: A Frequent Pattern Tree Aproach". Data Mining and Knowledge Discovery, 2014

[7] Wahyudin, Ari Wijaya, Swamardika. "Data Mning For Clustering Revenue Plain Expense Area (APBD) By Using K-Means Algorithm". International Journal Of Engineering And Emerging Technology, Vol. 2, No 1 Januari-June 2017

[8] Jiawei Han, Micheline Kamber, Jian Pei. "Data Mining Concepts and Techniques Third Edition”. Simon Fraser University Elsivier 2012

[9] Cristina Oprrea, Della Miora Popescu, Anca Gabriela Petrescu, Irina Barb. "Data Mining based Model To Improve University Management" Journal Of Science And Arts, 2017. 
\{ Halaman ini sengaja dikosongkan \} 